\title{
Extraction of Bioactive Compounds from Millingtonia hortensis for the Treatment of Dapsone Resistance in Leprosy
}

\author{
Anish Kumar ${ }^{1}$, Kshitija lyer ${ }^{2}$, Shanthi $\mathbf{V}^{1}$ and Ramanathan $\mathbf{K}^{1 *}$ \\ ${ }^{1}$ Industrial Biotechnology Division, School of Bio Sciences and Technology, VIT University, Vellore, Tamil Nadu, India \\ ${ }^{2}$ Medical Biotechnology Division, School of Bio Sciences and Technology, VIT University, Vellore, Tamil Nadu, India
}

\begin{abstract}
Medicinal plants have been the single most productive source of leads for the development of drugs thus played an important role in treating and preventing a variety of diseases throughout the world. In the present investigation, Millingtonia hortensis was examined for their antibacterial activity particularly against Mycobacterium leprae. Initially, the solvents such as methanol, acetone, benzene and petroleum ether were utilized to extract the chemical components from Millingtonia hortensis. Subsequently, the components were identified by means of GC-MS techniques. Moreover, molecular docking techniques were employed to determine the antibacterial activity of these compounds particularly against Mycobacterium leprae. Finally, Molinspiration and OSIRIS program were utilized to investigate the bioavailability and toxicity of the selected compounds. The results indicates that compounds such as DI-alpha-tocopherol, Vitamin E, Squalene isolated from Millingtonia hortensis could be the potential molecule for the treatment of new as well as dapsone resistance cases of leprosy. We believe that this study certainly be helpful for the experimental biologist in the near future.
\end{abstract}

Keywords: Antibacterial activity; GC-MS analysis; Millingtonia hortensis; Dapsone; Molecular docking

\section{Introduction}

Mycobacterium leprae causes a chronic infectious disease called Leprosy which is still a major concern at global level [1]. Macrophages and peripheral nerves (specifically the Schwann cells that ensheathe them in protective myelin) are the prime infection targets of this pathogen. M. leprae is critical as it cannot be cultured in artificial media, time consuming and infectious to human [2]. MDT introduced by WHO has been effective in reducing both the prevalence and incidence of leprosy globally [3-5]. Despite the decrease in prevalence of the disease, isolates resistant to one or more antibiotics have been detected in many areas. Resistance to the anti-leprosy drugs such as dapsone, rifampicin and ofloxacin evolves by amino acid substitution at the binding sites of these drugs [6-12]. The WHO Study Group on Chemotherapy of Leprosy for Control Programmes recommended the introduction of Multi-Drug Therapy (MDT) in 1982 in response to the serious threat to leprosy control posed by the widespread emergence of drug resistance. However, dapsone resistance continues to be reported even in areas of the world with successful implementation of MDT $[13,14]$. Concern has also been expressed about the development of drug resistance to rifampicin, as it is the most important component of the MDT regimen [15-27]. Most importantly, the literature evidences indicates that Thr53Val mutation confers resistance to first line drug called Dapsone $[28,29]$. This situation urges the researcher to identify the novel molecule against drug resistant folp1. In this aspect, development in the computational techniques is certainly helpful. The drug resistance determining region (DRDR) in the folP $1, \mathrm{rpoB}$, and gyr A genes have been proven to confer resistance to dapsone, rifampicin, and ofloxacin, respectively [30,31]. Most importantly, plants have high medicinal value due to some chemical active substances that produce a definite physiological action on human body and less chance for the development of resistance. The chemically active constituents of plants are alkaloids, tannin, flavonoid and phenolic compounds. Moreover, herbal extracts were showing a promising result in controlling both plant diseases particularly fungal and bacterial diseases [32,33]. Most importantly, the plant, Millingtonia hortensis, has high medicinal values and is used for indigenous treatment of variety of diseases including asthma, rheumatism, tuberculosis, cancer, antipyretic, sinusitis and as an cholagogue and tonic [34].

However, no evidences available related to the use of Millingtonia hortensis especially against the leprosy cases. Hence, in the present study, an attempt was made to isolate the antibacterial compound from the stem of Millingtonia hortensis Linn which belongs to the family Bignoniaceae, against drug resistant Mycobacterium leprae. Subsequently, computational techniques were also employed for further analysis. The results were analyzed in terms of binding energy, ADME (Absorption, Distribution, Metabolism and Excretion) and toxicity analysis. We sincerely hope that this study be useful to develop novel compounds against $M$. leprae.

\section{Materials and Methods}

\section{Plant material}

The fresh stem barks of Millingtonia hortensis Linn were collected from Botanical garden of VIT University in Vellore district in Tamil $\mathrm{Nadu}$, India during the month of January. The stem was washed thoroughly two to three times with running tap water and once with sterile distilled water and shade dried at room temperature. Shade dried barks of Millingtonia hortensis Linn were used to make powder and that powder was used for further experiments.

\section{Chemical used}

Solvent such as petroleum ether, benzene, methanol, acetone and

*Corresponding author: Ramanathan K, Industrial Biotechnology Division, Schoo of Bio Sciences and Technology, VIT University, Vellore- 632014, Tamil Nadu, India, Tel: +91 4162202545; Fax: +91 4162243092; E-mail: kramanathan@vit.ac.in

Received June 30, 2014; Accepted July 23, 2014; Published July 30, 2014

Citation: Kumar A, lyer K, Shanthi V, Ramanathan K (2014) Extraction of Bioactive Compounds from Millingtonia hortensis for the Treatment of Dapsone Resistance in Leprosy. J Microb Biochem Technol R1: 006. doi:10.4172/1948-5948.R1-006

Copyright: @ 2014 Kumar A, et al. This is an open-access article distributed under the terms of the Creative Commons Attribution License, which permits unrestricted use, distribution, and reproduction in any medium, provided the original author and source are credited 
Citation: Kumar A, lyer K, Shanthi V, Ramanathan K (2014) Extraction of Bioactive Compounds from Millingtonia hortensis for the Treatment of Dapsone Resistance in Leprosy. J Microb Biochem Technol R1: 006. doi:10.4172/1948-5948.R1-006

Page 2 of 6

nutrient agar were purchased from Hi media pvt Ltd used for all our experiments.

\section{Extraction of bioactive compound}

The dried stem bark powder were coarsely powdered and subjected to successive extraction by soxhlation [33]. The extraction was done with different solvents according to their increasing order of polarity such as petroleum ether, benzene, methanol and acetone. The resulting extracts were concentrated by rotary vacuum evaporator and evaporated to dryness by hot air oven [35]. The solvent of different polarity such as acetone, petroleum ether, benzene and methanol were used for extracting bioactive compound. Stock was prepared by weighing $5 \mathrm{mg}$ of dried extract and dissolving it in $5 \mathrm{ml}$ of DMSO. Further dilution was carried out to get $100,300,500$ and $900 \mu \mathrm{g} / \mathrm{ml}$ concentrations by using DMSO as solvent.

\section{Anti-bacterial activity determination}

E. coli was used as a test organism [36]. Well diffusion method [37] was used for the examining the antibacterial activity of the extract. Bacteria were inoculated on nutrient agar and were allowed to solidify. For each treatment three replicates were maintained. Four wells of 10 $\mathrm{mm}$ diameter were made in each of this agar plate. About $0.3 \mathrm{ml}$ of different concentration of plant extract were added into the well using sterilized dropping pipette and disc of kanamycin was added at the center of plates (as chemical bactericide for comparison) which were then incubated at $37^{\circ} \mathrm{C}$ for $20 \mathrm{hrs}$. Diameter of zone of inhibition was recorded for determining the antibacterial activity.

\section{GC-MS analysis}

GC-MS technique was used in this study to identify the components present in the extract. GC-MS technique was carried out at Vellore Institute of Technology (VIT) Vellore, Tamil Nadu. Compounds were separated by GC. The structures of the components were identified using a mass spectrophotometer [38]. GC-MS analysis of the extract was performed using a Perkin Elmer GC Clarus 680 system and gas chromatograph interfaced to a Mass Spectrometer Clarus 600 system (GC-MS) equipped with Elite-1 fused silica capillary column $(30 \mathrm{~m} \times$ $1 \mu \mathrm{l}$ was Mdf, composed of $100 \%$ Dimethyl poly siloxane). For GC-MS detection, an electron ionization energy system with ionization energy of $70 \mathrm{eV}$ was used. Helium gas $(99.999 \%)$ was used as the carrier gas at a constant flow rate of $1 \mathrm{ml} / \mathrm{min}$. and an injection volume of $1 \mu \mathrm{l}$ was employed (Split ratio of 10:1). Injector temperature was $250^{\circ} \mathrm{C}$. The initial oven temperature was programmed from $60^{\circ} \mathrm{C}$ for $2 \mathrm{~min}$, with an increase of $10^{\circ} \mathrm{C} / \mathrm{min}$ to $300^{\circ} \mathrm{C}$, ending with a $6 \mathrm{~min}$. Mass spectra were taken at $70 \mathrm{eV}$; a scan interval of 0.5 seconds and fragments from 50 to $600 \mathrm{Da}$. Total GC running time was $32 \mathrm{~min}$. The relative percentage amount of each component was calculated by comparing its average peak area to the total areas. Software adopted to handle mass spectra and chromatograms was a TurboMass Ver5.4.2. Compound identification was obtained by comparing the retention times with those of authentic compounds and the spectral data obtained from library data of the corresponding compounds.

\section{Homology modelling}

Homology modeling aimed to develop the structure of the folp1 target because point mutations in the target protein 'folP1' results in dapsone resistance while other targets such as 'rpoB' and 'gyrA' are responsible for rifampin and ofloxacin respectively $[39,40]$. Mycobacterium leprae (folp1) homologue sequence was retrieved from UniProtKB/TrEMBL database (Id: P0C0X1). NCBI-BLASTP search against Protein Data Bank (PDB) using Mycobacterium leprae as query sequence gave a number of homologous sequences. Among these sequences, PDB code: 1EYE (human) was chosen as a best template based on high sequence identity (77\%) to model 3-Dstructure of the Mycobacterium leprae. The Blosum62 scoring matrix was selected with a gap penalty of 11 and a gap extension penalty of 1 for the BLASTP analysis. The crystal structure of 1EYE A was solved at a resolution of $1.70 \AA$ which is in complex with 6-Hydroxymethylpterin monophosphate. Subsequently, MODELLER is a computer program that generates 3-D model structures of the proteins and their assemblies by satisfaction of spatial restraints. More generally, the input to the program is the alignment file (PAP/PIR formats), restraints on the spatial structure of the amino acid sequence(s) to be modeled [41]. The ligand structures were generated with the aid of SMILES string. The SMILES string deposited into the CORINA program to generate the structure of ligand molecules.

\section{Energy minimization}

Swiss-PdbViewer is used for energy minimization of the native protein (folp1) and mutant protein (thr53val) by repairing distorted geometries thereby releasing internal constraints. It includes a version of the GROMOS 43a1 force field. This force field allows to evaluate the energy of a structure as well as repair distorted geometries and to develop the best final structures with the shortest computer time $[42,43]$.

\section{Molecular docking}

Fire dock was used for docking between protein (native and mutant) and ligand (dapsone and compound obtained from GCMS analysis). It was used to predict the preferred orientation of one molecule to second when bound to each other to form stable complex. The ligand-protein pair wise interaction energies were calculated [37].

\section{ADME and toxicity analysis}

ADME describes the disposition of a pharmaceutical compound within an organism. The four criteria all influence the drug levels and kinetics of drug exposure to the tissues and hence influence the performance and pharmacological activity of the compound as a drug. ADME toxicity studies evaluate how a drug and/or its metabolites are absorbed, distributed, metabolized, and excreted from the body. Drug metabolism issues one of the primary reasons why drug candidates fail in clinical trials. Molinspiration was used for bioavailability analysis. All the data set molecules were subjected to the toxicity risk assessment by using Osiris program

\section{Results and Discussion}

\section{Extraction of bioactive compounds}

The bioactive compounds were successfully extracted from stem by soxhlation using solvents of different polarity like acetone, methanol, and petroleum ether. The extracts were then dried by employing rotary vacuum evaporator (Figure 1).

\section{Antibacterial activity determination}

Zone of inhibition was calculated for all the concentration and the best result was found to be of petroleum ether against test microorganism $E$. coli when compared to standard drug kanamycin. The results of zone of inhibition are given in Figure 2 and Table 1. 
Citation: Kumar A, Iyer K, Shanthi V, Ramanathan K (2014) Extraction of Bioactive Compounds from Millingtonia hortensis for the Treatment of Dapsone Resistance in Leprosy. J Microb Biochem Technol R1: 006. doi:10.4172/1948-5948.R1-006

Page 3 of 6

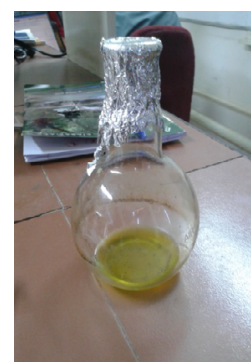

(a)

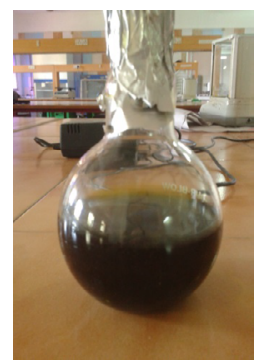

(b)

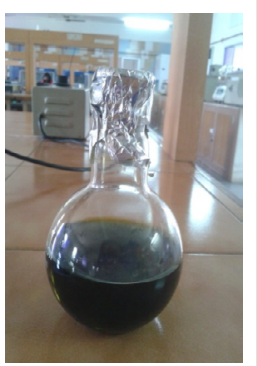

(c)

Figure 1: Extracts obtained after soxhlation (a) acetone (b) methanol (c) petroleum ether.

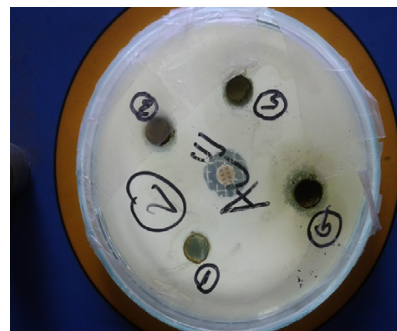

(a) acetone

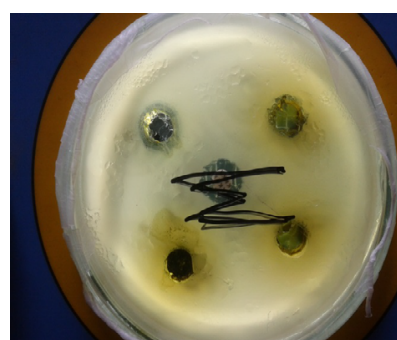

(b) methanol

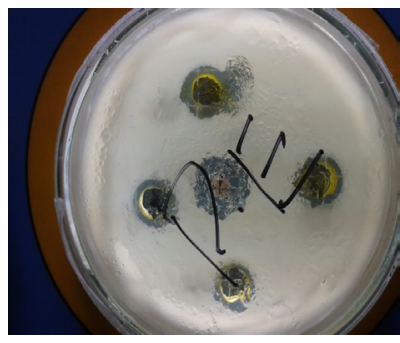

(c) petroleum ether

Figure 2: Petri plates depicting zone of inhibition for different solvents (a) acetone (b) methanol (c) petroleum ether.

\section{GC MS analysis}

GC-MS analysis was performed for Millingtonia hortensis in acetone and methanol extract shown in Figure 3 and 4 respectively. The compounds present in the petroleum ether extract of Millingtonia hortensis were identified by GC-MS analysis presented in Figures 3-5. The active principle Molecular Weight (MW), Concentration (\%), Molecular Formula (MF), and Retention Time (RT) is presented in Table 2. More than seven compounds were identified in the extract. The prevailing compounds were Dl-alpha-tocopherol (36.10\%), Squalene (35.55\%), Hexadecanoic acid, butyl ester (10.08\%), Methyl6, 9-octadecadienoate (9.57\%).

\begin{tabular}{|c|c|c|}
\hline S. No & Petroleum ether concentration $(\mathrm{mg} / \mathrm{ml})$ & Diameter (cm) \\
\hline 1 & 1 & 1 \\
\hline 2 & 3 & 1.52 \\
\hline 3 & 5 & 1.57 \\
\hline 4 & 9 & 1.65 \\
\hline S. No & Acetone concentration $(\mathrm{mg} / \mathrm{ml})$ & Diameter (cm) \\
\hline 1 & 1 & 0.4 \\
\hline 2 & 3 & 0.5 \\
\hline 3 & 5 & 0.51 \\
\hline 4 & 9 & 0.57 \\
\hline S. No & Methanol concentration (mg/ml) & Diameter (cm) \\
\hline 1 & 1 & 0.5 \\
\hline 2 & 3 & 0.75 \\
\hline 3 & 5 & 1 \\
\hline 4 & 9 & 1.5 \\
\hline S. No & Benzene concentration $(\mathrm{mg} / \mathrm{ml})$ & Diameter (cm) \\
\hline 1 & 1 & 0.52 \\
\hline 2 & 3 & 0.51 \\
\hline 3 & 5 & 0.52 \\
\hline 4 & 9 & 0.5 \\
\hline
\end{tabular}

Table 1: Results obtained by calculating zone of inhibition against E.coli.

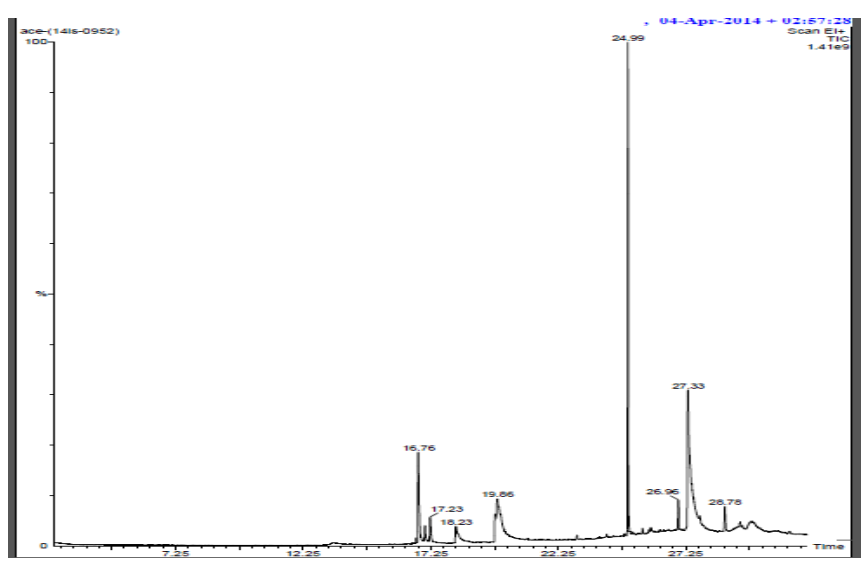

Figure 3: Chromatogram obtained from GC-MS analysis of acetone extract.

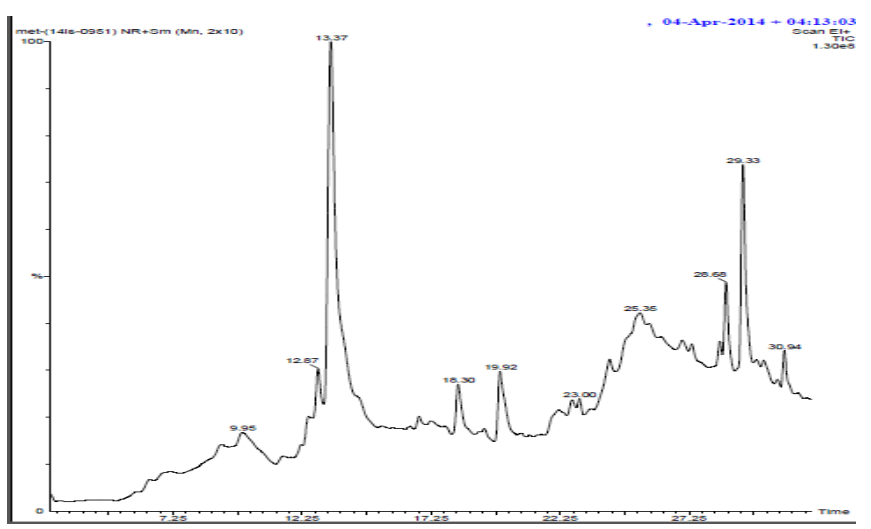

Figure 4: Chromatogram obtained from GC-MS analysis of methanol extract.

\section{Molecular docking}

Fire dock was used for docking native protein (folp1) and mutant protein (thr53val) against ligand (Dapsone and compounds obtained 
Citation: Kumar A, lyer K, Shanthi V, Ramanathan K (2014) Extraction of Bioactive Compounds from Millingtonia hortensis for the Treatment of Dapsone Resistance in Leprosy. J Microb Biochem Technol R1: 006. doi:10.4172/1948-5948.R1-006

Page 4 of 6

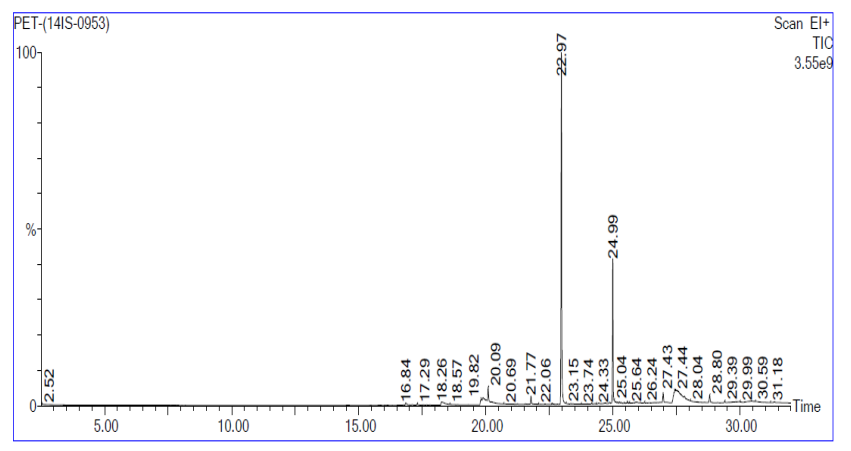

Figure 5: GC-MS pattern of Phytoconstituents present in petroleum ether obtained from Millingtonia hortensis.

\begin{tabular}{|c|c|c|c|c|c|}
\hline S. No & $\begin{array}{l}\text { Retention } \\
\text { Time }\end{array}$ & Name of the compound & $\begin{array}{l}\text { Molecular } \\
\text { Formula }\end{array}$ & $\begin{array}{l}\text { Molecular } \\
\text { Weight }\end{array}$ & $\begin{array}{l}\text { Peak } \\
\text { Area \% }\end{array}$ \\
\hline 1 & 19.82 & Bicyclo[4.1.0]heptane,7-pentyl & $\mathrm{C}_{12} \mathrm{H}_{22}$ & 166 & 2.98 \\
\hline 2 & 19.89 & Methyl6,9-octadecadienoate & $\mathrm{C}_{19} \mathrm{H}_{34} \mathrm{O}_{2}$ & 294 & 9.57 \\
\hline 3 & 20.09 & Hexadecanoicacid,butyl ester & $\mathrm{C}_{20} \mathrm{H}_{40} \mathrm{O}_{2}$ & 312 & 10.08 \\
\hline 4 & 21.771 & Octadecanoicacid, butyl ester & $\mathrm{C}_{22} \mathrm{H}_{44} \mathrm{O}_{2}$ & 340 & 1.91 \\
\hline 5 & 24.992 & Squalene & $\mathrm{C}_{30} \mathrm{H}_{50}$ & 410 & 35.55 \\
\hline 6 & 26.973 & Hentriacontane & $\mathrm{C}_{31} \mathrm{H}_{64}$ & 436 & 3.04 \\
\hline 7 & 27.468 & DI-alpha-tocopherol & $\mathrm{C}_{29} \mathrm{H}_{50} \mathrm{O}_{2}$ & 430 & 36.1 \\
\hline 8 & 27.523 & Vitamin $\mathrm{E}$ & $\mathrm{C}_{29} \mathrm{H}_{50} \mathrm{O}_{2}$ & 430 & 8.28 \\
\hline
\end{tabular}

Table 2: Components identified in petroleum ether of Millingtonia hortensis extract.

\begin{tabular}{|l|l|c|c|}
\hline S. No & Lead molecule & $\begin{array}{c}\text { Binding affinity with } \\
\text { native (Kcal/mol) }\end{array}$ & $\begin{array}{c}\text { Binding affinity with } \\
\text { mutant (Kcal/mol) }\end{array}$ \\
\hline 1 & Dapsone & -36.06 & -32.96 \\
\hline 2 & Bicyclo[4.1.0]heptane,7-pentyl & -28.36 & -38.79 \\
\hline 3 & Methyl6,9-octadecadienoate & -35.1 & -34.84 \\
\hline 4 & Hexadecanoicacid,butyl ester & -30.59 & -31.34 \\
\hline 5 & Octadecanoic acid, butyl ester & -34.98 & -25.17 \\
\hline 6 & Squalene & -45.12 & -42.01 \\
\hline 7 & Hentriacontane & -34.84 & -29.88 \\
\hline 8 & Dl-alpha-tocopherol & -48.17 & -46.86 \\
\hline 9 & Vitamin E & -48.17 & -46.86 \\
\hline
\end{tabular}

Table 3: Binding affinity of native and mutant protein against dapsone and bioactive compounds. from stem extract of petroleum ether solvent). It was used to predict the preferred orientation of one molecule to second when bound to each other to form a stable complex. Several compounds were selected through a series of studies based on binding energy analysis and we have obtained three top scoring compounds viz. Dl-alpha-tocopherol, Vitamin $\mathrm{E}$ and Squalene from various compounds listed in Table 3.

\section{ADME and toxicity analysis}

All the compound were subjected to toxicity assessment studies by using Osiris online programme which reveals that all the compound showed very good ADME profile which minimizes the toxicity risk of dapsone analogues in human being. Among all the bioactive compounds subjected for toxicity assessment, compound 2, 3, 6 , 7,8 and 9 were found to be free from high risks of undesired effects like mutagenicity or a poor intestinal absorption. In Molinspiration programme, all the Dapsone analogues showed better results for drug absorption, including intestinal absorption, bioavailability, $\mathrm{CaCO}_{2}$ permeability and blood-brain barrier penetration (Tables 4 and 5).

\section{Conclusion}

Phytochemicals of plant source with pharmacological importance is an alternative approach for the modern medication against several toxic envenomations. According to recent studies, usage of phytochemicals are reported as the most reliable and efficient compounds with therapeutic significance. Computational studies provide an insight for developing novel inhibitors against bacterial pathogen $M$. leprae using plant based bioactive chemicals and by comparing those bioactive chemicals with the drug already existing in the market. The inhibitory efficiency of selected compounds were computed and analyzed through homology modeling, energy minimization, molecular docking and ADME and toxicity analysis. The molecular docking studies revealed that compounds such as Dl-alpha-tocopherol, Vitamin E, Squalene, Bicyclo[4.1.0]heptane,7-pentyl-, Methyl 6,9-octadecadienoate isolated from Millingtonia hortensis could be the potential molecule for the treatment of new as well as resistance cases of leprosy. Though further studies like ADME and toxicity analysis suggests that Bicyclo[4.1.0] heptane,7-pentyl,Methyl 6,9-octadecadienoate is the major compound that it could prove as an effective drug against $M$. leprae and as a substitute of first line drug Dapsone.

\section{Acknowledgement}

The authors express deep sense of gratitude to the management of Vellore Institute of Technology for all the support, assistance and constant encouragements to carry out this work.

\begin{tabular}{|c|c|c|c|c|c|c|c|c|}
\hline S. No & Compound & Mutagenic & Tumorigenic & Irritant & $\begin{array}{c}\text { Reproductive } \\
\text { effective }\end{array}$ & cLogP & Drug likeness & Drug score \\
\hline 1 & Dapsone & $\mathrm{Y}$ & $\mathrm{Y}$ & $\mathrm{N}$ & $\mathrm{Y}$ & 1.01 & 0.84 & 0.16 \\
\hline 2 & Bicyclo[4.1.0]heptane,7-pentyl- & $\mathrm{N}$ & $\mathrm{N}$ & $\mathrm{N}$ & $\mathrm{N}$ & 4.95 & -18.82 & 0.32 \\
\hline 3 & Methyl6,9-octadecadienoate & $\mathrm{N}$ & $\mathrm{N}$ & $\mathrm{N}$ & $\mathrm{N}$ & 6.89 & -35.73 & 0.22 \\
\hline 4 & Hexadecanoic acid, butyl ester & $\mathrm{N}$ & $\mathrm{N}$ & $\mathrm{Y}$ & $\mathrm{N}$ & 7.81 & -29.23 & 0.11 \\
\hline 5 & Octadecanoic acid, butyl ester & $\mathrm{N}$ & $\mathrm{N}$ & $\mathrm{Y}$ & $\mathrm{N}$ & 8.71 & -29.23 & 0.09 \\
\hline 6 & Squalene & $\mathrm{N}$ & $\mathrm{N}$ & $\mathrm{N}$ & $\mathrm{N}$ & 13.1 & -3.52 & 0.14 \\
\hline 7 & Hentriacontane & $\mathrm{N}$ & $\mathrm{N}$ & $\mathrm{N}$ & $\mathrm{N}$ & 14.15 & -20.4 & 0.11 \\
\hline 8 & DI-alpha-tocopherol & $\mathrm{N}$ & $\mathrm{N}$ & $\mathrm{N}$ & $\mathrm{N}$ & 9.64 & -4.78 & 0.12 \\
\hline 9 & Vitamin E & $\mathrm{N}$ & $\mathrm{N}$ & $\mathrm{N}$ & $\mathrm{N}$ & 9.64 & -4.78 & 0.12 \\
\hline
\end{tabular}

Table 4: Toxicity analysis results using OSIRIS software depicting drug score. 
Citation: Kumar A, lyer K, Shanthi V, Ramanathan K (2014) Extraction of Bioactive Compounds from Millingtonia hortensis for the Treatment of Dapsone Resistance in Leprosy. J Microb Biochem Technol R1: 006. doi:10.4172/1948-5948.R1-006

\begin{tabular}{|l|l|l|l|l|l|l|}
\hline S.No & Compound name & $\begin{array}{l}\text { Molecular } \\
\text { weight }\end{array}$ & nON & nOHNH & nviolations & nrotb \\
\hline 1 & Dapsone & 248.307 & 4 & 4 & 0 & 2 \\
\hline 2 & Bicyclo[4.1.0]heptane,7-pentyl & 166.308 & 0 & 0 & 1 & 4 \\
\hline 3 & Methyl6,9-octadecadienoate & 294.479 & 2 & 0 & 1 & 15 \\
\hline 4 & Hexadecanoic acid,butyl ester & 312.538 & 2 & 0 & 1 & 18 \\
\hline 5 & Octadecanoic acid, butyl ester & 340.592 & 2 & 0 & 1 & 20 \\
\hline 6 & Squalene & 410.73 & 0 & 0 & 1 & 15 \\
\hline 7 & Hentriacontane & 436.853 & 0 & 0 & 1 & 28 \\
\hline 8 & Dl-alpha-tocopherol & 430.717 & 2 & 1 & 1 & 12 \\
\hline 9 & Vitamin E & 430.717 & 2 & 1 & 1 & 12 \\
\hline
\end{tabular}

Table 5: Bioavailability analysis by using molinspiration program.

\section{References}

1. You EY, Kang TJ, Kim SK, Lee SB, Chae GT (2005) Mutations in genes related to drug resistance in Mycobacterium leprae isolates from leprosy patients in Korea. J Infect 50: 6-11.

2. Goulart IM, Goulart LR (2008) Leprosy: diagnostic and control challenges for a worldwide disease. Arch Dermatol Res 300: 269-290.

3. Jacobson RR, Hastings RC (1976) Rifampin-resistant leprosy. Lancet 2: 13041305.

4. Ji B, Perani EG, Petinom C, Grosset JH (1996) Bactericidal activities of combinations of new drugs against Mycobacterium leprae in nude mice. Antimicrob Agents Chemother 40: 393-399.

5. Hackel C, Houard S, Portaels F, van Elsen A, Herzog A, et al. (1990) Specific identification of Mycobacterium leprae by the polymerase chain reaction. Mo Cell Probes 4: 205-210.

6. Ebenezer GJ, Norman G, Joseph GA, Daniel S, Job CK (2002) Drug resistantMycobacterium leprae--results of mouse footpad studies from a laboratory in south India. Indian J Lepr 74: 301-312.

7. Cambau E, Perani E, Guillemin I, Jamet P, Ji B (1997) Multidrug-resistance to dapsone, rifampicin, and ofloxacin in Mycobacterium leprae. Lancet 349: 103-104

8. Maeda S, Matsuoka M, Nakata N, Kai M, Maeda Y, et al. (2001) Multidrug resistant Mycobacterium leprae from patients with leprosy. Antimicrob Agents Chemother 45: 3635-3639.

9. Matsuoka M, Kashiwabara Y, Namisato M (2000) A Mycobacterium leprae isolate resistant to dapsone, rifampin, ofloxacin and sparfloxacin. Int $\mathrm{J}$ Lepr Other Mycobact Dis 68: 452-455.

10. Cambau E, Bonnafous P, Perani E, Sougakoff W, Ji B, et al. (2002) Molecular detection of rifampin and ofloxacin resistance for patients who experience relapse of multibacillary leprosy. Clin Infect Dis 34: 39-45

11. Matsuoka M, Kashiwabara Y, Liangfen Z, Goto M, Kitajima S (2003) A second case of multidrug-resistant Mycobacterium leprae isolated from a Japanese patient with relapsed lepromatous leprosy. Int J Lepr Other Mycobact Dis 71: 240-243

12. Matsuoka M, Budiawan T, Aye KS, Kyaw K, Tan EV, et al. (2007) The frequency of drug resistance mutations in Mycobacterium leprae isolates in untreated and relapsed leprosy patients from Myanmar, Indonesia and the Philippines. Lepr Rev 78: 343-352.

13. Butlin CR, Neupane KD, Failbus SS, Morgan A, Britton WJ (1996) Drug resistance in Nepali leprosy patients. Int J Lepr Other Mycobact Dis 64: 136141.

14. dela Cruz E, Cellona RV, Balagon MV, Villahermosa LG, Fajardo TT Jr, et al. (1996) Primary dapsone resistance in Cebu, The Philippines; cause for concern. Int J Lepr Other Mycobact Dis 64: 253-256.

15. Cambau E, Perani E, Guillemin I, Jamet P, Ji B (1997) Multidrug-resistance to dapsone, rifampicin, and ofloxacin in Mycobacterium leprae. Lancet 349: 103-104.

16. Maeda S, Matsuoka M, Nakata N, Kai M, Maeda Y, et al. (2001) Multidrug resistant Mycobacterium leprae from patients with leprosy. Antimicrob Agents Chemother 45: 3635-3639.

17. Matsuoka M, Kashiwabara Y, Namisato M (2000) A Mycobacterium leprae isolate resistant to dapsone, rifampin, ofloxacin and sparfloxacin. Int $\mathrm{J}$ Lepr Other Mycobact Dis 68: 452-455.

18. Cambau E, Bonnafous P, Perani E, Sougakoff W, Ji B, et al. (2002) Molecular detection of rifampin and ofloxacin resistance for patients who experience relapse of multibacillary leprosy. Clin Infect Dis 34: 39-45.

19. Gupta UD, Katoch VM (1999) Drug resistance in leprosy: lessons from past and future perspective. Indian J Lepr 71: 451-463.

20. Cambau E, Carthagena L, Chauffour A, Ji B, Jarlier V (2006) Dihydropteroate synthase mutations in the folP1 gene predict dapsone resistance in relapsed cases of leprosy. Clin Infect Dis 42: 238-241.

21. Honore N, Cole ST (1993) Molecular basis of rifampin resistance in Mycobacterium leprae. Antimicrob Agents Chemother 37: 414-418.

22. Honoré N, Perrani E, Telenti A, Grosset J, Cole ST (1993) A simple and rapid technique for the detection of rifampin resistance in Mycobacterium leprae. Int $\mathrm{J}$ Lepr Other Mycobact Dis 61: 600-604.

23. Williams DL, Gillis TP (2004) Molecular detection of drug resistance in Mycobacterium leprae. Lepr Rev 75: 118-130.

24. Williams DL, Waguespack C, Eisenach K, Crawford JT, Portaels F, et al. (1994) Characterization of rifampin-resistance in pathogenic mycobacteria. Antimicrob Agents Chemother 38: 2380-2386.

25. Zhang L, Namisato M, Matsuoka M (2004) A mutation at codon 516 in the rpoB gene of Mycobacterium leprae confers resistance to rifampin. Int J Lepr Other Mycobact Dis 72: 468-472.

26. Kai M, Matsuoka M, Nakata N, Maeda S, Gidoh M, et al. (1999) Diaminodiphenylsulfone resistance of Mycobacterium leprae due to mutations in the dihydropteroate synthase gene. FEMS Microbiol Lett 177: 231-235.

27. Pettit JH, Rees RJ (1964) Sulphone Resistance In Leprosy. An Experimental And Clinical Study. Lancet 2: 673-674.

28. Pearson JM, Rees RJ, Waters MF (1975) Sulphone resistance in leprosy. A review of one hundred proven clinical cases. Lancet 2: 69-72.

29. Senthil R, Sarojini D (2012) Antimicrobial Activities Of Psidium Guajava L Lea Extract. International Journal of Institutional Pharmacy and Life Sciences 2 59-62.

30. Gopalakrishnan S, Hill AW (2012) Antimicrobial activity of the leaves of Myxopyrum serratulum. International Journal of Pharmaceutical Sciences and Drug Research 4: 31-34.

31. Abiramasundari P, Priya V, Jeyanthi GP (2011) Evaluation of the Antibacteria activity of Cocculus hirsutus. Journal for Drugs And Medicines 3: 26-31.

32. Sharma M, Puri S and Sharma PD (2007) Antifungal activity of Millingtonia Hortensis, Indian Journal of Pharmaceutical Sciences, 69: 599 -601.

33. Nagaraja M S and Padmaa M Paarakh (2011) Antibacterial Activity of Millingtonia hortensis Linn Stem Bark. Asian J Phar Biol Res 1: 384-386 .

34. Kumari A, Sharma RA (2013) A Review on Millingtonia hortensis Linn. Int Pharm Sci Rev Res 19: 85-92.

35. Jetty A, lyengar DS (2000) Antimicrobial activity of millingtonia hortensis leaf extract. Pharm Biol 38: 157-160.

36. Sivaperumal P, Ramasamy P, Jacob Inbaneson, Ravikumar S (2010) Screening of antibacterial activity in mangrove leaf bioactive compound agains antibacterial resistant clinical isolates. World Journal Of Fish And Marine Sciences 22: 348-353.

37. Al-Sohaibani S, Murugan K (2012) Anti-biofilm activity of Salvadora persica on cariogenic isolates of Streptococcus mutans: in vitro and molecular docking studies. Biofouling 28: 29-38.

38. Kalaiselvan A, Gokulakrishnan K, Anand T (2012) Gas chromatographyMass Spectrum analysis of bioactive components of the ethanol extract of Andrographis Paniculata. J Pharm Biomed Sci 20

39. Nakata N, Kai M, Makino M (2011) Mutation analysis of the Mycobacterium leprae folP1 gene and dapsone resistance. Antimicrob Agents Chemother 55 762-766.

40. Kim SK, Lee SB, Kang TJ, Chae GT (2003) Detection of gene mutations related with drug resistance in Mycobacterium leprae from leprosy patients using Touch-Down (TD) PCR. FEMS Immunol Med Microbiol 36: 27-32. 
Citation: Kumar A, Iyer K, Shanthi V, Ramanathan K (2014) Extraction of Bioactive Compounds from Millingtonia hortensis for the Treatment of Dapsone Resistance in Leprosy. J Microb Biochem Technol R1: 006. doi:10.4172/1948-5948.R1-006

Page 6 of 6

41. Awale M, Kumar V, Saravanan P, Mohan CG (2010) Homology modeling and atomic level binding study of Leishmania MAPK with inhibitors. J Mol Model 16: $475-488$.

42. Xu D, Zhang Y (2011) Improving the physical realism and structural accuracy of protein models by a two-step atomic-level energy minimization. Biophys $J$ 101: 2525-2534.

43. Swartz PD, Ichiye T (1997) Protein contributions to redox potentials of homologous rubredoxins: an energy minimization study. Biophys J 73: 27332741. 